model of agent, host, and environment ${ }^{28}$ Research that allows for interplay among these factors is likely to be most productive. ${ }^{29} \mathrm{We}$ already know much about the environments in which multiple sclerosis is common and about relevant host factors (including those with a genetic basis). The agent(s) remains a mystery, although an infectious agent has long been suspected. More than 20 viruses have been linked with multiple sclerosis over the years, but in no case has the association proved causal. ${ }^{30}$ Recent reports implicating a retrovirus have not been confirmed. ${ }^{31-33}$ Alter et al suggested that multiple sclerosis might be an age dependent host response to measles and other childhood infections. ${ }^{34} 35$

Another lesson from the history of epidemiology is that diseases may be preventable before their causes are properly understood. Thus the Royal Navy knew how to prevent scurvy more than a century before the discovery of vitamins, and John Snow's work led to steps to control cholera long before the cholera vibrio was identified. ${ }^{28}$ Some optimists hope that the vaccination programmes against measles will lead to a decline in multiple sclerosis. That remains to be seen, but the search for environmental factors should continue.

D C G SKEGG

Professor of Preventive and Social Medicine,

University of Otago,

Dunedin,

New Zealand

1 Acheson ED. The epidemiology of multiple sclerosis. In: Matthews WB, ed. McAlpine's multiple sclerosis. Edinburgh: Churchill Livingstone, 1985: 3-46.

2 Kurtzke JF. Epidemiology of multiple sclerosis. In: Vinken PJ, Bruyn GW, Klawans HL, Koetsier JC, eds. Demyelinating diseases. Amsterdam: Elsevier, 1985: 259-87. (Handbook of clinical neurology; vol 47.)

3 Wynn DR, Rodriguez M, O'Fallon WM, Kurland LT. Update on the epidemiology of multiple sclerosis. Mayo Clin Proc 1989;64:808-17.

4 Norman JE, Kurtzke JF, Beebe GW. Epidemiology of multiple sclerosis in US veterans. 2. Latitude, climate and the risk of multiple sclerosis. $\mathcal{F}$ Chronic Dis 1983;36:551-9.

5 Spielman RS, Nathanson N. The genetics of susceptibility to multiple sclerosis. Epidemiol Rev 1982;4:45-65

6 Acheson ED. Epidemiology of multiple sclerosis. Br Med Bull 1977;33:9-14.

7 Bhigiee AI. Multiple sclerosis in a black patient. $S$ Afr Med F 1987;72:873-5.

8 Miller DH, Hornabrook RW, Dagger J, Fong R. Ethnic and HLA patterns related to multiple sclerosis in Wellington, New Zealand. $\mathcal{F}$ Neurol Neurosurg Psychiatry 1986;49:43-6.
Skegg DCG, Corwin PA, Craven RS, Malloch JA, Pollock M. Occurrence of multiple sclerosis in the north and south of New Zealand. $\mathcal{F}$ Neurol Neurosurg Psychiatry 1987;50:134-9.

10 Palffy G. MS in Hungary, including the gypsy population. In: Kuroiwa Y, Kurland LT, eds. Multiple sclerosis east and west. Basel: Karger, 1982: 149-57.

11 Detels R, Visscher BR, Malmgren RM, Coulson AH, Lucia MV, Dudley JP. Evidence for lower susceptibility to multiple sclerosis in Japanese-Americans. Am f Epidemiol 1977;105:303-10.

2 Morariu MA, Linden M. Multiple sclerosis in American blacks. Acta Neurol Scand 1980;62:180-7.

13 Kurtzke JF, Beebe GW, Norman JE. Epidemiology of multiple sclerosis in US veterans: 1. Race, sex, and geographic distribution. Neurology 1979;29:1228-35.

14 Batchelor JR. Immunological and genetic aspects of multiple sclerosis. In: Matthews WB, ed. McAlpine's multiple sclerosis. Edinburgh: Churchill Livingstone, 1985: 281-301.

$15 \mathrm{McD}$ conald WI. The mystery of the origin of multiple sclerosis. 7 Neurol Neurosurg Psychiatry 1986;49:113-23.

16 Ebers GC, Bulman DE, Sadovnick AD, et al. A population based study of multiple sclerosis in twins. N Englf Med 1986;315:1638-42.

17 Kinnunen E, Juntunen J, Ketonen L, et al. Genetic susceptibility to multiple sclerosis. A co-twin study of a nationwide series. Arch Neurol 1988;45:1108-11.

18 Ebers GC, Bulman D. The geography of MS reflects genetic susceptibility [Abstract]. Neurology 1986;36(suppl 1): 108 .

19 Swingler RJ, Compston DAS. The distribution of multiple sclerosis in Britain. 7 Neurol Neurosurg Psychiatry 1986;49:1115-24.

20 Poskanzer DC, Terasaki PI, Prenney LB, Sheridan JL, Park, MS. Multiple sclerosis in the Orkney and Shetland Islands. 3: Histocompatibility determinants. F Epidemiol Community Health 1980;34:253-7.

21 Francis DA, Batchelor JR, McDonald WI, et al. Multiple sclerosis in northeast Scotland. Brain 1987;110:181-96.

22 Miller DH, Hammond SR, McLeod JG, Purdie G, Skegg DCG. Multiple sclerosis in Australia and New Zealand: Are the determinants genetic or environmental? $\mathcal{F}$ Neurol Neurosurg Psychiatry 1990;53:903-5.

23 Fawcett J, Skegg DCG. Geographic distribution of MS in New Zealand: evidence from hospital admissions and deaths. Neurology 1988;38:416-8.

24 Hammond SR, de Wytt C, Maxwell IC, et al. The epidemiology of multiple sclerosis in Queensland, Australia. F Neurol Sci 1987;80:185-204.

25 Williams ES, McKeran RO. Prevalence of multiple sclerosis in a south London borough. BMf 1986;293:237-9.

26 Dean G, Brady R, McLoughlin H, Elian M, Adelstein AM. Motor neurone disease and multiple sclerosis among immigrants to Britain. British fournal of Preventive and Social Medicine 1977;31:141-7.

27 Elian M, Nightingale S, Dean G. Multiple sclerosis among United Kingdom born children of immigrants from the Indian subcontinent, Africa and the West Indies. 7 Neurol Neurosurg Psychiatry 1990;53:906-11.

28 Lilienfeld AM, Lilienfeld DE. Foundations of epidemiology. 2nd ed. New York: Oxford University Press, 1980.

29 Compston DAS, Vakarelis BN, Paul E, McDonald WI, Batchelor JR, Mims CA. Viral infection in patients with multiple sclerosis and HLA-DR matched controls. Brain 1986;109:325-44.

30 Johnson RT. Viral aspects of multiple sclerosis. In: Vinken PJ, Bruyn GW, Klawans HL, Koetsier JC, eds. Demyelinating diseases. Amsterdam: Elsevier, 1985: 319-36. (Handbook of clinical JC, eds. Demyelinat

31 Koprowski H, DeFreitas EC, Harper ME, et al. Multiple sclerosis and human T cell lymphotropic retroviruses. Nature 1985;318:154-60.

32 Weinshenker BG, Dekaban G, Rice GPA. Retroviruses and multiple sclerosis. 1. Analysis of seroreactivity by Western blot and radioimmune assay. Neurology 1990;40:1251-3.

33 Oksenberg JR, Mantegazza R, Sakai K, Bernard CCA, Steinman L. HTLV-1 sequences are not detected in peripheral blood genomic DNA or in brain cDNA of multiple sclerosis patients. Ann Neurol 1990;28:574-7.

34 Alter M. Is multiple sclerosis an age-dependent host response to measles? Lancet 1976;i:456-7.

35 Alter $M$, Zhen-xin Z, Davanipour Z, et al. Multiple sclerosis and childhood infections. Neurology 1986;36:1386-9.

\title{
Picking up the tab for erythropoietin
}

\section{General practitioners should prescribe it-just as they prescribe growth hormone}

One of the satisfactions of renal medicine is that chronic dialysis works. This treatment has kept some patients alive for more than 20 years. Nevertheless, survival is not cheap for government or patient. Maintenance haemodialysis or continuous ambulatory peritoneal dialysis costs $£ 10000-£ 12000$ a year, and about 8000 patients receive such treatment each year in the United Kingdom. Only recently has the struggle for sufficient dialysis facilities ended: the memory of "negative selection"-patients left to die of chronic renal failure - is still fresh. ${ }^{12}$ About a quarter of patients receiving dialysis still feel unwell because of anaemia caused by erythropoietin deficiency. Treatment with erythropoietin is available, but it is very expensive. A year's treatment for one patient costs $£ 3000-£ 5000$. Now a new battle is enjoined.

Taylor and colleagues have presented their findings in a group of patients receiving dialysis before, during, and after an eight week course of maintenance erythropoietin (p 272). ${ }^{3}$ The hormone was provided for trial purposes by the manufacturers. Because funds were not available to purchase further supplies, treatment had to be stopped. In all 12 patients the wretched symptoms of erythropoietin deficiency anaemia recurred, with an appreciable psychological morbidity.
Regrettably these are not isolated observations; many British renal units experience similar difficulties. It is not easy to estimate how many patients have the difficulties described by Taylor et al. The suppliers estimate that about 1300 patients have been treated with free erythropoietin made available for clinical trials and believe that most patients continue to enjoy the benefits of the hormone purchased from renal budgets. Yet their estimate is difficult to reconcile with Taylor et al's paper and what one hears on the grapevine. Certainly not all those who need erythropoietin are receiving it; perhaps 200-300 patients are missing out. Renal budgets that are underfunded (and hence overspent) are to blame. The treatment is successful, ${ }^{45}$ and the lack of funds to purchase supplies is scandalous. Money from a general hospital budget spent on erythropoietin would reduce the available acute sector funds even further. The Department of Health has, however, made it clear that central funding will not be provided for this desirable hormone.

Faced with these difficulties, what should doctors do? Blood transfusions, though ameliorating symptoms for a few weeks, are not the answer. Supplies are short, repeated transfusion leads to iron overload, and most important is the 
real risk of sensitisation of patients receiving dialysis to human leucocyte antigens, which may make matching for a transplant difficult or impossible. A successfully transplanted kidney produces erythropoietin such that the anaemia of chronic renal failure is corrected by three to four months after transplantation. Unfortunately, the number of patients waiting for a graft kidney is increasing year by year. Perhaps two fifths of all dialysis patients are too old or too infirm to hazard the risk of transplant surgery and immunosuppression.

An obvious way forward when the renal budget is too small is to ask the patient's general practitioner to prescribe the hormone. This arrangement exists for growth hormone. The Secretary of State for Health has specifically directed that growth hormone, which costs $£ 5000-£ 10000$ a year (supplier's estimate) should be prescribed by family doctors. Many general practitioners are prescribing erythropoietin, but not all are happy to do so.

Some think that it is improper to prescribe drugs for patients whose treatments are not directly under their clinical control, ${ }^{6}$ and they cite the Department of Health's backing for this position. It has issued reminders to practitioners that prescribers should be in clinical control of all patients for whom they prescribe. Presumably this is yet another attempt to restrict funding without consideration for patients' welfare and contradicts previous statements from the Department of Health that all who require a drug will receive it.

The way around this difficulty? Reluctant general practitioners should be asked to take full responsibility for their patients' welfare and renal physicians should provide just advice when the patient is not in hospital. The time and effort that this would take for a few hundred patients would be well worth while. Erythropoietin so improves the quality of life in selected patients that to withhold it, in 1991, in the United Kingdom is unacceptable.

\section{ROGER GABRIEL}

Renal Physician,

St Mary's Hospital,

London W2 1NY

1 Challah S, Wing AJ, Bauer R, Morris RW, Schroeder SA. Negative selection of patients for dialysis and transplantation. $B M \mathcal{F} 1984 ; 288: 1119-22$.

Berlyne GM. Over 50 and uraemic = death. The failure of the British National Health Service to provide adequate dialysis facilities. Nephron 1982;31:189-90.

3 Taylor J, Henderson IS, Mactier RA. Erythropoietin withdrawal. BM7 1991;302:272-3.

4 Schaefer RM, Hörl WH, Massry SG. Treatment of renal anemia with recombinant human erythropoietin. Am F Nephrol 1989;9:353-62.

5 Gabriel R. Wanted: funds for a treatment that really works. $B M \mathcal{1}$ 1989;299:64.

6 Bogle I. Passing on problems to the general practitioners. Independent on Sunday $1990 \mathrm{Dec}$ 2:17(col 6).

\section{Prospective or retrospective: What's in a name?}

\section{The shorthand classification of a study may create confusion}

The recent adoption of the more informative structured abstract by several medical journals has rehashed an old debate on the use of the words "prospective" and "retrospective" in clinical and epidemiological research. ${ }^{1}$ The structured abstract requires a description of the study design. Editors like it to be crisp and clear and, above all, short. Hence the words prospective and retrospective have started a second life- and seeded new confusion.

Epidemiology knows of two schools of thought regarding the use of these words. One school, originally centred on epidemiologists at Johns Hopkins, calls any follow up study prospective even if it is clearly a historical cohort, ${ }^{23}$ maintaining that any follow up moves forward in time. They therefore use the word retrospective for what the other school calls "case-control." Their reasoning is that in the casecontrol study the investigator in effect looks back from present disease to past exposure. The other school, originally centred on Harvard, ${ }^{+}$knows of two types of follow up studies - the prospective and the retrospective-both distinct from case-control research. According to the second tradition, the strictest definition of a prospective study might run thus: a follow up study in which a disease outcome is related to baseline characteristics that were originally collected with this particular follow up in mind. The investigators collected the baseline information according to a protocol that included the follow up and then aged together with their subjects. In contrast, in a retrospective follow up study the investigator has a bright idea, searches some conveniently available dataoriginally collected for other purposes - and adds a follow up about his or her favourite disease up to the present. The second school maintains that it sticks to the common use of the prefixes "retro" and "pro," as indicators of the time course of a study from the point of view of the investigator. ${ }^{4}$

In the past feelings ran high, and present positions remain entrenched. The Dictionary of Epidemiology still calls "cohort," "follow up," and "prospective" synonyms, irrespective of whether the data are past or present, ${ }^{5}$ while clinical epidemiologists and theoreticians detail all the distinctions. ${ }^{67}$ Smart researchers have, of course, learnt that the chances of funding and publication are improved by calling a study prospective. The qualifier retrospective has been defamed too often in the past, accused of all the potential biases of case-control research. ${ }^{8}$

In the $B M Y$ 's recent clinical and epidemiological papers adorned with the new type of abstract the word prospective abounds. A closer look at the details of the methods in these papers, however, soon shows that the use of the word wildly transgresses the boundaries of the venerable epidemiological conflict of terminologies. Several case series are called prospective, apparently because the patients were entered consecutively, even when there is no inkling of any prespecified research plan: data were retrieved from more or less consecutive old records because of a new interest. Oddly enough, plain case-control comparisons within such patient series also happen to be labelled prospective, presumably because the patients accrued over a specified period. Almost all follow up studies, whether of past or present cohorts, wave prospective flags. Some are prospective according to the strictest definition. In others researchers who retrieved an old population survey, a previous case series, or a forgotten clinical trial and who added a further follow up for a purpose unrelated to the original venture proceed to call the amalgam prospective. Furthermore, when data from a follow up study of whatever sort are reanalysed for a new purpose the new publication almost invariably retains the label prospective; the proper name should, of course, be "secondary analysis." Finally, a common superfluous use of the word is in the expression "prospective randomised controlled trial." As people cannot be randomised in the past a randomised controlled trial cannot be anything but prospective. Given the confusionwhich is not limited to this journal - the words prospective and retrospective have lost all meaning. From spotting them 